\title{
EFFECT ON COMPRESSIVE STRENGTH OF CONCRETE USING SEA SAND AS A PARTIAL REPLACEMENT FOR FINE AGGREGATE
}

\author{
W. Sai Deepak ${ }^{1}$, G. Tirupathi Naidu ${ }^{2}$ \\ ${ }^{I}$ B.E, Civil Engineering Department, Sanketika Vidya Parishad Engineering College, Andhra Pradesh, India \\ ${ }^{2}$ Associate professor and Head of the Department, Civil Engineering Department, Sanketika Vidya Parishad \\ Engineering College, Andhra Pradesh, India
}

\begin{abstract}
Concrete is a major construction material used in the construction now a days. It is a composite material containing cement, fine aggregate, coarse aggregate and water. Fine aggregate is required in large quantities for manufacturing of concrete. Generally river sand is used as a fine aggregate. Due to increase in the utilization of concrete in construction sector, the need for river sand has been increased enormously. Limitations have been laid on the large scale mining of river sand from river beds. In this context there are cases of illegal mixing of sea sand with river sand. This paper mainly presents the practical study of the compressive strength of the concrete in which sea sand was used as fine aggregate is partially or completely replaced. For this study first control specimens were laid for M20 grade concrete. The fine aggregate proportion from the design mix was replaced partially in percentages of 20\%, 40\%, 60\%, 80\% and 100\% by sea sand. Compressive strength test was conducted on the various concrete specimens with various fine aggregate proportions and the results were tabulated. The compressive strengths of concrete specimens for respective mix proportions were tested at 7, 14 and 28 days of water curing. The behavior of concrete by partial replacement of fine aggregate with sea sand has been studied. With the increase in the percentage of sea sand replacement in concrete, the compressive strength of the concrete significantly reduced.
\end{abstract}

Keywords: Concrete, Fine Aggregate, sea sand, Compressive strength

\section{INTRODUCTION}

The boom in the construction sector is a direct result of economic growth. This rapid growth leads to fierce competition for resource rights of fine aggregate and coarse aggregate from riverbeds. This results in illegal mining of river beds for river sand which in turn causes environmental problems. Due to this scarcity of river sand, the contractors are mixing sea sand with river sand.

This study is a basic practical study on the compressive strength of concrete made by using sea sand as a partial replacement to fine aggregate. In this the fine aggregate was replaced by sea sand in various percentages.

When sea sand is mixed with cement in place of normal river sand to make concrete for buildings, structural issues in buildings arise.

\section{NEED FOR PRESENT STUDY}

River sand is an essential raw material in construction industry. Especially during monsoons the sources of river sand are unpredictable due to the rise in river water table. Also governments have imposed norms on the mining and utilization of river sand for construction purposes. Due to these reasons different construction companies have started mixing sea sand illegally with river sand. In this scenario there is a need to study the mechanical properties of concrete with sea sand as a partial replacement to fine aggregate.

\section{AIM AND OBJECTIVE}

The objectives of this study are:

$>$ To study the practical utilization of sea sand as fine aggregate partially or completely.

$>\quad$ To determine the compressive strength of concrete with different percentages of sea sand as fine aggregate as partial replacement.

\section{SCOPE OF THE STUDY}

This work involved the practical study of compressive strength of concrete made using sea sand as fine aggregate as a partial replacement. In this study the sea sand sample was taken from east peninsular of India which was Visakhapatnam. The sample was taken on the sea shore and not involving the sea sand that is close to the water.

\section{MIX DESIGN}

The mix design for the control specimens was done based on IS: $10262-1982$. The water to cement ratio taken was 0.5 . The compressive strength of concrete depends on the properties of the materials used in the concrete. In general the various requirements of concrete are strength, workability and economy. Based on the physical properties of the materials used in the concrete mix design was done. For the present study two trial mixes with different proportioning were laid and the one with better economy and workability was selected for the study. 
Table -1: Mix design for M20 grade

\begin{tabular}{|l|l|l|l|}
\hline Cement & $\begin{array}{l}\text { Fine } \\
\text { Aggregate }\end{array}$ & $\begin{array}{l}\text { Coarse } \\
\text { Aggregate }\end{array}$ & $\begin{array}{l}\text { Water to } \\
\text { Cement ratio }\end{array}$ \\
\hline 1 & 1.55 & 3.51 & 0.5 \\
\hline
\end{tabular}

\section{MATERIALS USED IN CONCRETE}

\subsection{Cement}

An OPC 53 grade Maha gold cement was used in this study. The physical properties of the cement used were found based on the respective IS codes

Table -2: Properties of cement

\begin{tabular}{|c|c|c|c|}
\hline S.NO & Particulars of test & Test results & $\begin{array}{l}\text { Requirement } \\
\text { as per IS } \\
\text { Code }\end{array}$ \\
\hline 1 & $\begin{array}{l}\text { Fineness of } \\
\text { cement }\end{array}$ & $96 \%$ & $\begin{array}{lr}\text { IS: } & 4031 \\
\text { PART } 1 & 1996 \\
\end{array}$ \\
\hline 2 & $\begin{array}{l}\text { Standard } \\
\text { Consistency }\end{array}$ & $30 \%$ & $\begin{array}{l}\text { IS 4031 - } \\
1996 \\
\text { (Part 4) }\end{array}$ \\
\hline 3 & Setting time & & \\
\hline $\mathrm{a}$ & Initial setting time & $45 \mathrm{~min}$ & $\begin{array}{l}\text { As per } \\
\text { IS :12269- } \\
2013 \\
\text { 30min, } \\
\text { Minimum }\end{array}$ \\
\hline $\mathrm{b}$ & Final setting time & $195 \mathrm{~min}$ & $\begin{array}{l}\text { As per } \\
\text { IS: 12269- } \\
2013 \\
600 \mathrm{~min}, \\
\text { Maximum }\end{array}$ \\
\hline
\end{tabular}

\subsection{Fine Aggregate}

The fine aggregate used in this study was clean river sand purchased near Visakhapatnam. The following tests on fine aggregate were done based on IS 2386-1968 (Part 3)

Table -3: Properties of Fine aggregate

\begin{tabular}{|l|l|l|}
\hline S.NO & Particulars of test & Test results \\
\hline 1 & Specific gravity & 2.56 \\
\hline 2 & Fineness modulus & $3.4 \%$ \\
\hline 3 & Bulking of sand & $4 \%$ \\
\hline 4 & Sieve analysis & Zone II \\
\hline
\end{tabular}

\subsection{Coarse Aggregate}

In the present investigation crushed stone aggregate of $20 \mathrm{~mm}$ size was used. The following are the physical properties of coarse aggregate used

Table -4: Properties of Coarse aggregate

\begin{tabular}{|l|l|l|}
\hline S.NO & Particulars of test & Test results \\
\hline 1 & Specific gravity & 2.86 \\
\hline 2 & Crushing value & $19.5 \%$ \\
\hline 3 & Impact value & $23.1 \%$ \\
\hline 4 & Fineness modulus & $7.24 \%$ \\
\hline
\end{tabular}

\section{RESULTS AND DISCUSSIONS}

The water cured concrete specimens were tested at the age of 7,14 and 28 days. The specimens were tested in compression testing machine of capacity 200T. The following are the results obtained after testing.

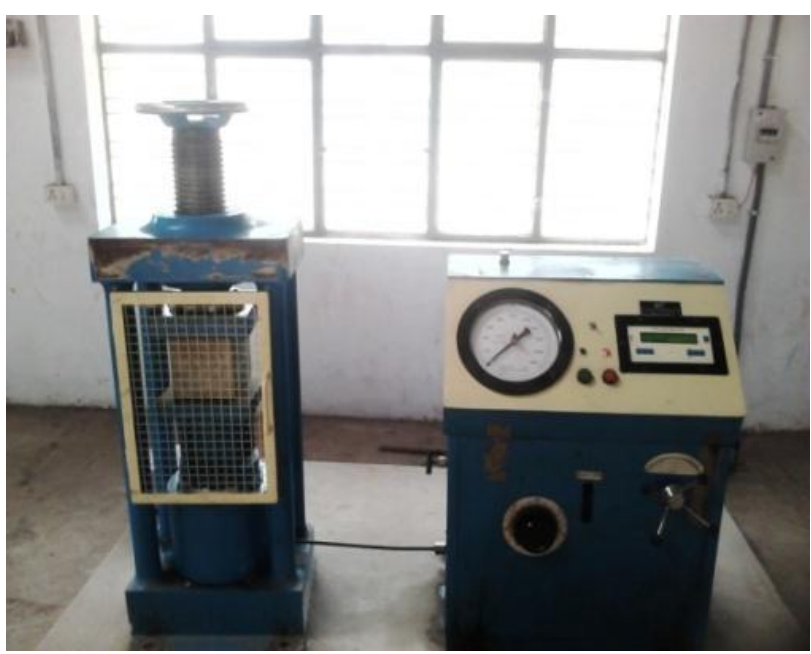

Fig -1: Compression testing machine

Table -5: 7 days compressive strength

\begin{tabular}{|c|c|c|c|}
\hline Mix & $\begin{array}{l}\text { Different } \\
\text { mixes }\end{array}$ & $\begin{array}{l}\text { Compressive } \\
\text { strength } \\
\text { (MPa) }\end{array}$ & \% Reduction \\
\hline 1 & $\begin{array}{l}100 \% \text { river } \\
\text { sand }\end{array}$ & 17.39 & --- \\
\hline 2 & $\begin{array}{l}80 \% \text { river } \\
\text { sand and } 20 \% \\
\text { sea sand }\end{array}$ & 15.85 & 8.85 \\
\hline 3 & $\begin{array}{l}60 \% \text { river } \\
\text { sand and } 40 \% \\
\text { sea sand }\end{array}$ & 13.98 & 19.6 \\
\hline 4 & $\begin{array}{l}40 \% \text { river } \\
\text { sand and } 60 \% \\
\text { sea sand }\end{array}$ & 12.7 & 26.96 \\
\hline 5 & $\begin{array}{l}20 \% \text { river } \\
\text { sand and } 80 \% \\
\text { sea sand }\end{array}$ & 10.57 & 39.21 \\
\hline 6 & $100 \%$ sea sand & 9.62 & 44.68 \\
\hline
\end{tabular}

Table -6: 14 days compressive strength

\begin{tabular}{|c|c|c|c|}
\hline Mix & $\begin{array}{l}\text { Different } \\
\text { mixes }\end{array}$ & $\begin{array}{l}\text { Compressive } \\
\text { strength } \\
\text { (MPa) }\end{array}$ & \% Reduction \\
\hline 1 & $\begin{array}{ll}100 \% & \text { river } \\
\text { sand } & \\
\end{array}$ & 21.92 & --- \\
\hline 2 & $\begin{array}{l}80 \% \text { river } \\
\text { sand and } 20 \% \\
\text { sea sand }\end{array}$ & 17.31 & 21.03 \\
\hline 3 & $\begin{array}{l}60 \% \text { river } \\
\text { sand and } 40 \% \\
\text { sea sand }\end{array}$ & 16.20 & 26.09 \\
\hline 4 & $\begin{array}{l}40 \% \text { river } \\
\text { sand and } 60 \% \\
\text { sea sand }\end{array}$ & 14.38 & 34.4 \\
\hline
\end{tabular}




\begin{tabular}{|l|l|l|l|}
\hline 5 & $\begin{array}{l}20 \% \text { river } \\
\text { sand and 80\% } \\
\text { sea sand }\end{array}$ & 13.08 & 40.32 \\
\hline 6 & $100 \%$ sea sand & 11.7 & 46.6 \\
\hline
\end{tabular}

Table -7: 28 days compressive strength

\begin{tabular}{|l|l|l|l|}
\hline Mix & Different mixes & $\begin{array}{l}\text { Compressive } \\
\text { strength } \\
\text { (MPa) }\end{array}$ & \% Reduction \\
\hline 1 & $100 \%$ river sand & 27.81 & --- \\
\hline 2 & $\begin{array}{l}80 \% \text { river sand } \\
\text { and 20\% sea sand }\end{array}$ & 18.29 & 34.23 \\
\hline 3 & $\begin{array}{l}60 \% \text { river sand } \\
\text { and 40\% sea sand }\end{array}$ & 37.15 & 34.33 \\
\hline 4 & $\begin{array}{l}40 \% \text { river sand } \\
\text { and 60\% sea sand }\end{array}$ & $\begin{array}{l}\text { 15.32 } \\
\text { and 80\% sea sand }\end{array}$ & 14.08 \\
\hline 5 & $100 \%$ sea sand & 12.84 & 53.82 \\
\hline
\end{tabular}

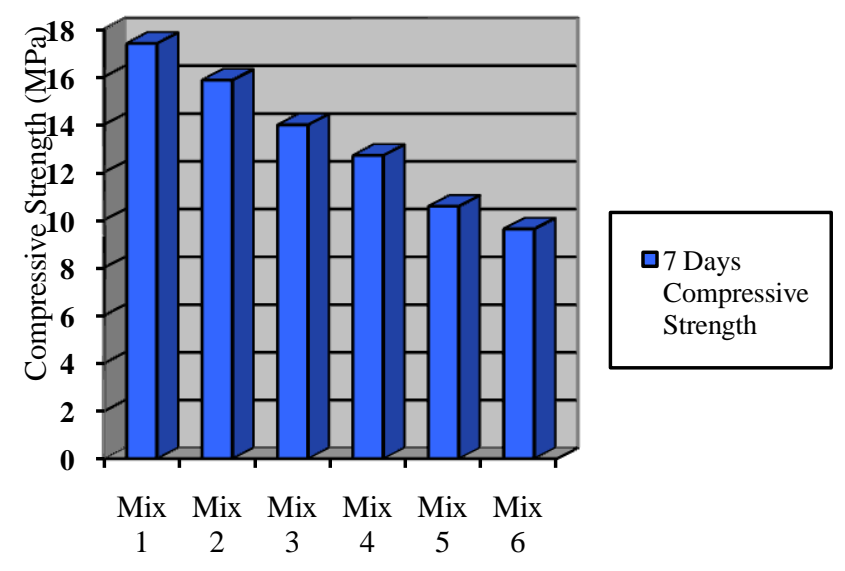

Chart -1: Variation of 7 days compressive strength for different mixes

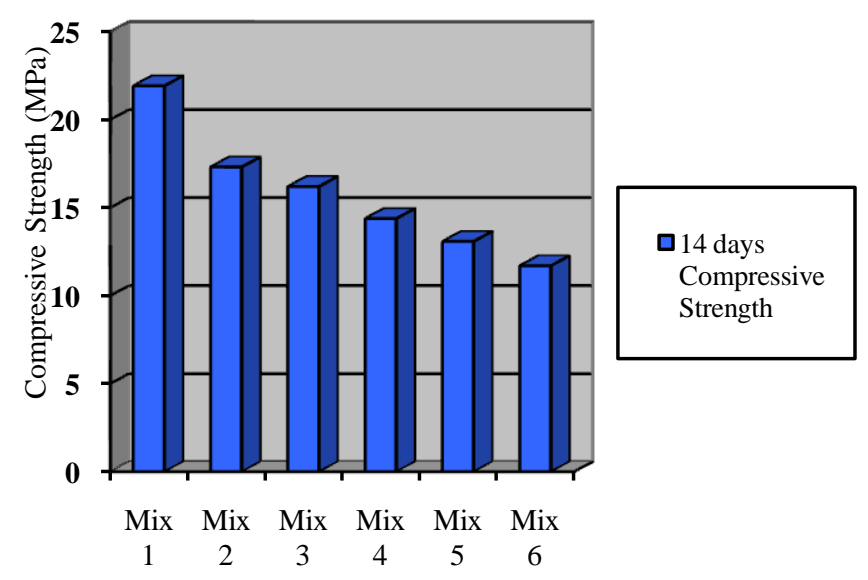

Chart -2: Variation of 14 days compressive strength for different mixes

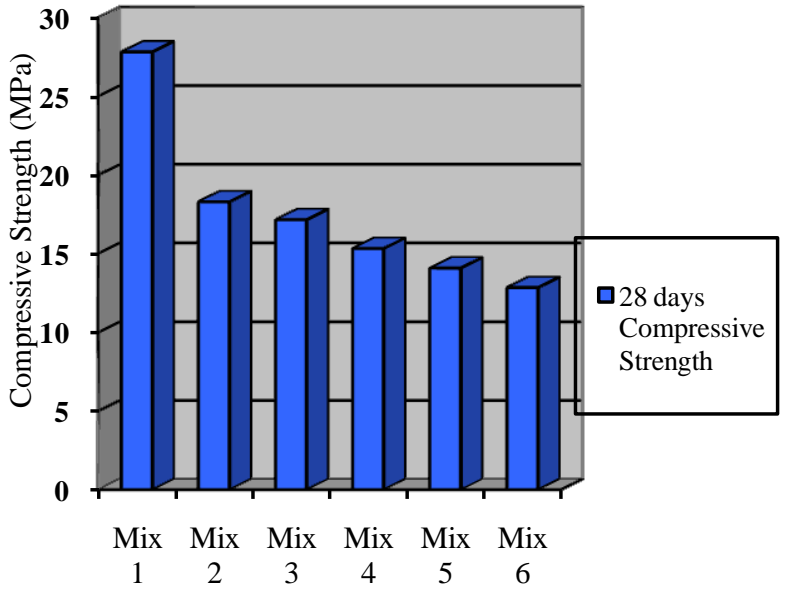

Chart -3: Variation of 28 days compressive strength for different mixes

The results show that there is a constant decrease in the compressive strength with the increase in the quantity of sea sand in the concrete. The decrease in the strength is gradual for the different mixes used. The reduction in strength also increased with the increase in the age of concrete.

\section{CONCLUSION}

- In case of $20 \%$ replacement of sea sand as fine aggregate the Characteristic compressive strength is reduced by $34.23 \%$.

- At $40 \%$ replacement of fine aggregate with sea sand the Characteristic compressive strength is reduced by $38.33 \%$.

- $60 \%$ replacement of fine aggregate with sea sand reduces the Characteristic compressive strength by $44.9 \%$.

- In case of $80 \%$ replacement of sea sand as fine aggregate the Characteristic compressive strength is reduced by $49.37 \%$.

- It is observed that for $100 \%$ replacement of sea sand as fine aggregate in concrete compressive strength is reduced by $53.82 \%$.

- Usage of Sea sand in concrete found there is a significant reduction in strength of the concrete.

- $\quad$ The reduction in compressive strength of concrete for 7 days is $44.68 \%$, for 14 days is $46.6 \%$ and for 28 days is $53.82 \%$.

- The reduction in characteristic compressive strength of the concrete is significant for partial replacement of sea sand as fine aggregate.

\section{REFERENCES}

[1] D. A. R. Dolage, M. G. S. Dias and C. T. Ariyawansa, "Offshore Sand as a Fine Aggregate for Concrete Production", British Journal of Applied Science \& Technology, 3(4): 813-825, 2013. 
[2] Do-Gyeum Kim, Myung-Sug Cho and Jong-Suk Lee, "The Effects of Chloride on Durability of Concrete Mixed With Sea Sand", US-China Education Review A, ISSN 2161-623X, May 2013, Vol. 3, No. 5, 325-331

[3] Keisaburo KATANO, Nobufumi TAKEDA, Yoshikazu ISHIZEKI and Keishiro IRIYA, "Properties and Application of Concrete Made with Sea Water and Un-washed Sea Sand", The International Conference on Sustainable Construction Materials and Technologies.

[4] S.R.De.S.Chandrakeerthy, "Sustainability of Sea Sand as a Fine Aggregate for Concrete Production".

\section{BIOGRAPHIES}

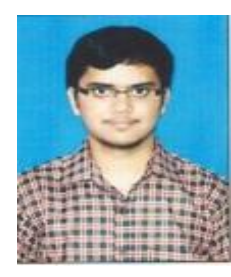

Mr. W. Sai Deepak is a resident of Visakhapatnam, Andhra Pradesh. He received his Bachelors degree in Civil Engineering from Sanketika Vidya Parishad Engineering College. Presently he is pursuing Masters in Structural Engineering and Natural Disaster Management in GITAM university, Visakhapatnam.

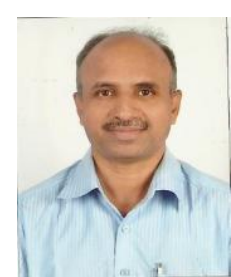

G.T.Naidu, The author presently working as Associate Professor in Sanketika Vidya Parishad Engineering College, PM Palem, Visakhapatnam doing his Research at GITAM College of Engineering, GITAM University and having experience 26 years of industrial, 4 years of teaching, guiding the students at Graduate and Post Graduate level 